LUNG CANCER

\title{
Relationship between reduced forced expiratory volume in one second and the risk of lung cancer: a systematic review and meta-analysis
}

\author{
S Wasswa-Kintu, W Q Gan, S F P Man, P D Pare, D D Sin
}

Thorax 2005;60:570-575. doi: 10.1136/thx.2004.037135

Background: Individuals with severely impaired lung function have an increased risk of lung cancer. Whether milder reductions in forced expiratory volume in 1 second $\left(\mathrm{FEV}_{1}\right)$ also increase the risk of lung

See end of article for authors' affiliations

....................

Correspondence to: Dr D D Sin, James Hogg iCAPTURE Center for Cardiovascular and Pulmonary Research, St Paul's Hospital, Room \#368A, 1081 'Burrard Street, Vancouver, BC, Canada V6Z 1Y6; dsin@ mrl.ubc.ca

Received

3 November 2004

Accepted 8 April 2005 cancer is controversial. Moreover, there is little consensus on whether men and women have similar risks for lung cancer for similar decreases in $\mathrm{FEV}_{1}$.

Methods: A search was conducted of PubMed and EMBASE from January 1966 to January 2005 and studies that examined the relationship between $\mathrm{FEV}_{1}$ and lung cancer were identified. The search was limited to studies that were population based, employed a prospective design, were large in size $1 \geqslant 5000$ participants), and adjusted for cigarette smoking status.

Results: Twenty eight abstracts were identified, six of which did not report $\mathrm{FEV}_{1}$ and eight did not adjust for smoking. Included in this report are four studies that reported $\mathrm{FEV}_{1}$ in quintiles. The risk of lung cancer increased with decreasing $\mathrm{FEV}_{1}$. Compared with the highest quintile of $\mathrm{FEV}_{1}(>100 \%$ of predicted), the lowest quintile of $\mathrm{FEV}_{1}(<\sim 70 \%$ of predicted) was associated with a 2.23 fold ( $95 \%$ confidence interval (CI) 1.73 to 2.86$)$ increase in the risk for lung cancer in men and a 3.97 fold increase in women $195 \% \mathrm{Cl}$ 1.93 to 8.25$)$. Even relatively small decrements in $\mathrm{FEV}_{1}(\sim 90 \%$ of predicted) increased the risk for lung cancer by $30 \%$ in men $(95 \% \mathrm{Cl} 1.05$ to 1.62 ) and 2.64 fold in women (95\% $\mathrm{Cl} 1.30$ to 5.31 ).

Conclusion: Reduced $\mathrm{FEV}_{1}$ is strongly associated with lung cancer. Even a relatively modest reduction in $\mathrm{FEV}_{1}$ is a significant predictor of lung cancer, especially among women. ung cancer is a major public health problem worldwide. In 2000, 328 million people died from lung cancer -globally. ${ }^{1}$ In Europe, 266000 men and 64000 women died from lung cancer in $1995 .{ }^{2}$ In the US there were over 170000 new cases of lung cancer and more than 160000 deaths related to lung cancer in 2004. ${ }^{3}$ This makes lung cancer the leading cause of cancer deaths in both men and women. Indeed, in the US, lung cancer causes more deaths than the next three most common cancers combined (colon cancer, $\mathrm{n}=48$ 100; breast cancer, $\mathrm{n}=40000$; and prostate cancer, $\mathrm{n}=30200)$. $^{3}$

The leading cause of lung cancer is cigarette smoking. Other risk factors include exposures to certain occupational hazards, combustion generated carcinogens, and ambient radiation. ${ }^{45}$ Some have argued that reduced lung function is another important risk factor for lung cancer. ${ }^{6-8}$ However, several epidemiological questions regarding this relationship remain unanswered. Firstly, since individuals with reduced lung function frequently have a significant smoking history, it is not certain whether the relationship between lung function and lung cancer is real or is simply confounded by the effects of smoking. Secondly, it is not known whether the relationship between impaired lung function and lung cancer is dose dependent or threshold dependent. Thirdly, even if there is a significant relationship between these two parameters, it is not known whether sex modifies this relationship. To address these questions we conducted a systematic review and meta-analysis of population based studies of the relationship between lung function and lung cancer risk.

\section{METHODS}

\section{Search for relevant studies}

Using PubMed (1966-2004) and EMBASE databases, we conducted a comprehensive literature search to identify relevant studies published before January 2005 that examined the relationship between forced expiratory volume in 1 second $\left(\mathrm{FEV}_{1}\right)$ and lung cancer. We used a disease specific search term (lung neoplasm*) combined with lung function specific search terms (FEV, $\mathrm{FEV}_{1}$, forced expiratory volume, lung function) in all our searches. The electronic searches were supplemented by scanning the reference lists from retrieved articles to identify additional studies that may have been missed during the initial search. We also contacted the primary authors of the study for clarification of data where necessary.

\section{Study selection and data abstraction}

The primary outcome of this systematic review was to compare the relative risk of lung cancer among subjects who had impaired lung function, as measured by $\mathrm{FEV}_{1}$, against those who had "normal" lung function at baseline assessment. To mitigate publication bias, we limited our search to studies that (1) were population based and did not select participants on the basis of disease; (2) employed a prospective design; (3) were large in size (at least 5000 participants at baseline); (4) used standardised methods for measuring $\mathrm{FEV}_{1} ;(5)$ adjusted for important confounders including age, sex, race, height, and smoking status; and (6) divided the cohort into quintiles. The latter criterion allowed us to determine the shape of the relationship between $\mathrm{FEV}_{1}$ and lung cancer.

From each relevant article two investigators (SW, WQG) abstracted the following information: first author, publication year, population sampled, sample size, lung cancer incidence or mortality, follow up time, age, sex, smoking history, $\mathrm{FEV}_{1}$, and other factors (table 1). Any questions or discrepancies regarding these data were resolved through iteration and consensus. 


\begin{tabular}{|c|c|c|c|c|c|c|c|c|c|c|c|}
\hline Author & Year & Population & $\begin{array}{l}\text { Sample } \\
\text { size }\end{array}$ & $\begin{array}{l}\text { No of } \\
\text { deaths }\end{array}$ & $\begin{array}{l}\text { Follow up } \\
\text { time } \\
\text { (years) }\end{array}$ & $\begin{array}{l}\text { Mean (SD) } \\
\text { age } \\
\text { (years) }\end{array}$ & $\begin{array}{l}\text { Male } \\
(\%)\end{array}$ & $\begin{array}{l}\text { Current } \\
\text { smokers } \\
\text { (\%) }\end{array}$ & $\begin{array}{l}\text { FEV }_{1} \\
\text { (\% predicted } \\
\text { or litres (II)) }\end{array}$ & End point & Covariate \\
\hline Hole $^{10}$ & 1996 & $\begin{array}{l}\text { Renfrew and } \\
\text { Paisley, West } \\
\text { Scotland }\end{array}$ & 15411 & 4439 & 15 & NR & 45.8 & $\begin{array}{l}\text { Male: } 45^{*} \\
\text { Female: } 46^{*}\end{array}$ & $\begin{array}{l}\text { Male: } 73 \% \\
\text { Female: } 70 \%\end{array}$ & Mortality & $\begin{array}{l}\text { Age, cigarette smoking, } \\
\text { diastolic blood pressure, } \\
\text { serum cholesterol } \\
\text { concentration, BMI, social } \\
\text { class }\end{array}$ \\
\hline Kuller" & 1990 & $\begin{array}{l}\text { High risk men } \\
\text { ( } 92 \% \text { white) for } \\
\text { coronary heart } \\
\text { disease in USA }\end{array}$ & 12866 & 119 & 10.5 & $46(5.5)$ & 100 & 64 & 3.21 I or $88 \%$ & Mortality & $\begin{array}{l}\text { Age, height, number of } \\
\text { cigarettes per day, } \\
\text { thiocyanate, age at which } \\
\text { smoking began, use of filter } \\
\text { cigarettes, tar and nicotine } \\
\text { content, alcoholic drinks/ } \\
\text { week, diastolic blood } \\
\text { pressure, cholesterol }\end{array}$ \\
\hline Mannino $^{12}$ & 2003 & $\begin{array}{l}\text { General civilian } \\
\text { population in } \\
\text { USA }\end{array}$ & 5402 & 113 & 18 & $47(14)$ & 45.2 & 42 & 89 & Mortality & $\begin{array}{l}\text { Age, sex, race, smoking } \\
\text { status, pack-years }\end{array}$ \\
\hline $\begin{array}{l}\text { Van Den } \\
\text { Eeden }^{13}\end{array}$ & 1992 & $\begin{array}{l}\text { North } \\
\text { California, } \\
\text { USA }\end{array}$ & 171311 & 1514 & 9 & 42 (NR) & 46.3 & $\begin{array}{l}\text { Male: } 51 \\
\text { Female: } 40\end{array}$ & $\begin{array}{l}\text { Male: } 3.091 \\
\text { Female: } 2.191\end{array}$ & Incidence & $\begin{array}{l}\text { Age, former and current } \\
\text { smokers, smoking duration, } \\
\text { quantity, and inhalation }\end{array}$ \\
\hline
\end{tabular}

\section{Statistical methods}

Quintile 5 was defined as the group with the best $\mathrm{FEV}_{1}$ and quintile 1 as the group with the worst $\mathrm{FEV}_{1}$. For the primary end point we included all incident cases of lung cancer or deaths from lung cancer, whichever were reported in the original study. There were no studies in which both of these variables were reported. A weighted mean difference technique was used to pool the original data together. The weighted mean difference was derived using an inverse variance weighted method. ${ }^{9}$ For each outcome the heterogeneity of the results across the studies was tested using a Cochran Q test. If significant heterogeneity was observed $(p<0.10)$, a random effects model—which assigns a weight to each study based on individual study variance as well as between study variance-was used to pool the results together. In the absence of significant heterogeneity a fixed effects model was used. ${ }^{9}$ Data analysis was conducted for men and women separately and combined. All analyses were conducted using Review Manager Version 4.2 (Revman; Cochrane Collaboration, Oxford, UK).

\section{RESULTS}

The study selection process is summarised in fig 1 . The electronic literature search yielded 333 citations from PubMed and 16 from EMBASE. The abstracts of these articles were reviewed for suitability. The reasons for exclusion are summarised in fig 1 . In all, we identified four studies which met the inclusion and exclusion criteria and were used in the analyses. ${ }^{10-13}$ In three of these studies ${ }^{10} 1113$ we abstracted the salient data from published reports and in the fourth ${ }^{12}$ we used the public use data files from the National Center for Health Statistics. ${ }^{14}$ The relevant baseline data from each of the selected studies are summarised in table 1 and the $\mathrm{FEV}_{1}$ data for each quintile group are summarised in table 2. In total, the analysis included 204990 participants of whom 6185 had or died from lung cancer. The average age of the participants ranged from 42 to 47 years at baseline across the original studies. The follow up time was 9-18 years (table 1 ).

After adjustments for important covariates such as age, cigarette smoking, and body mass index, participants in quintile 5 (the group with the best $\mathrm{FEV}_{1}$ ) had the lowest risk of lung cancer while those in quintile 1 (the group with the worst $\mathrm{FEV}_{1}$ ) had the highest risk of lung cancer (table 3 ). Surprisingly, even those in quintiles 3 and 4 , who had relatively well preserved lung function (mean $\mathrm{FEV}_{1} \sim 80$ $100 \%$ of predicted), also had an increased risk of lung cancer. The relationship was particularly notable in women where those in quintiles 3 and 4 had risks of lung cancer that were 3.5 and 2.6 fold higher, respectively, than those in quintile 5.

The relationship between $\mathrm{FEV}_{1}$ quintiles and the incidence of lung cancer in both men and women is summarised in table 3 and illustrated in fig 2. The slope of the relationship was significantly steeper in women than in men $(p<0.001)$. Moreover, for every quintile, the relative risk of lung cancer

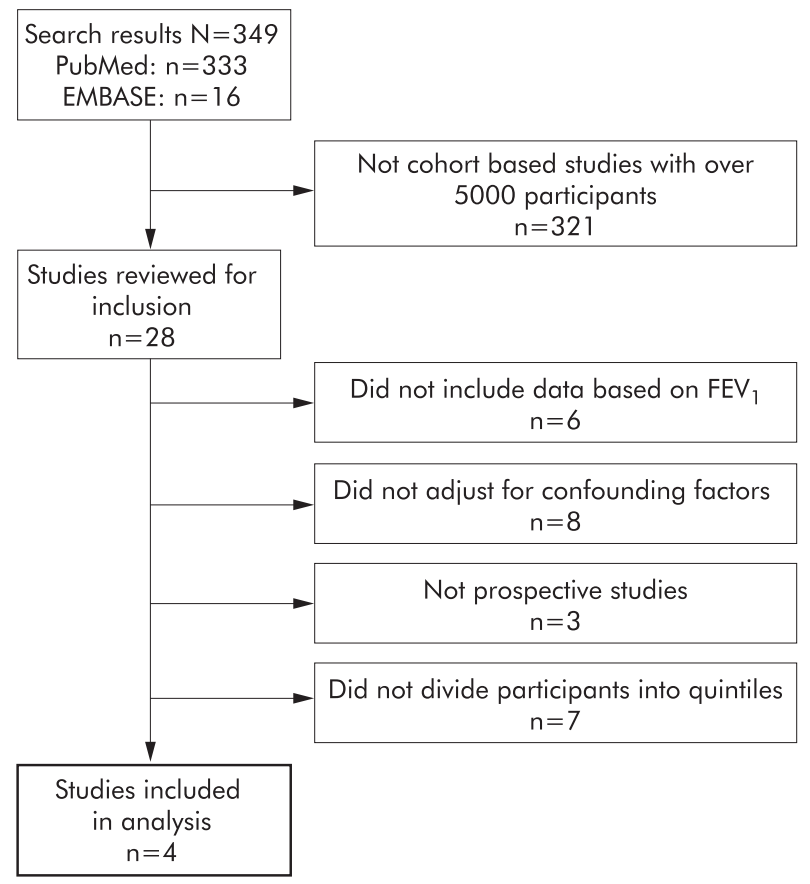

Figure 1 Study selection process. $\mathrm{FEV}_{1}$, forced expiratory volume in 1 second. 
Table 2 Lung function levels (\% predicted) in quintile groups for each study

\begin{tabular}{lccccc}
\hline & Quintile 1 & Quintile 2 & Quintile 3 & Quintile 4 & Quintile 5 \\
\hline Men & & & & & \\
Hole & $\leqslant 73$ & $74-87$ & $88-97$ & $98-108$ & $>108$ \\
Kuller $^{11 *}$ & $\leqslant 73$ & $74-85$ & $86-93$ & $94-101$ & $\geqslant 102$ \\
Mannino $^{12}$ & $\leqslant 75$ & $76-85$ & $86-92$ & $93-101$ & $\geqslant 102$ \\
Van Den Eeden $^{13 *}$ & $\leqslant 66$ & $67-79$ & $80-93$ & $94-104$ & $\geqslant 104$ \\
Women & & & & & \\
Hole & $\leqslant 74$ & $75-89$ & $90-100$ & $101-112$ & $\geqslant 113$ \\
Mannino $^{12}$ & $\leqslant 77$ & $78-87$ & $88-94$ & $95-103$ & $\geqslant 103$ \\
Van Den Eeden $^{13 *}$ & $\leqslant 60$ & $61-75$ & $76-85$ & $86-99$ & $\geqslant 100$ \\
\hline
\end{tabular}

*Percentage predicted values were calculated using Hankinson's equation ${ }^{49}$ with the assumption that the men in the study had a mean height of $170 \mathrm{~cm}$ and women had a mean height of $160 \mathrm{~cm}$, and the mean age was 46 years.

was higher in women than in men. These data suggest that the effects of reduced $\mathrm{FEV}_{1}$ are amplified in women.

In table 4 we have summarised the remaining large epidemiological studies that evaluated the relationship between $\mathrm{FEV}_{1}$ and the risk of lung cancer. Similar to the results of the present meta-analysis, all of these studies showed that reduced $\mathrm{FEV}_{1}$ was a significant risk factor for lung cancer. ${ }^{78}{ }^{15-20}$ These results could not be used in the metaanalysis, however, because of the marked heterogeneity in the way in which the data were collected and reported across the studies.

\section{DISCUSSION}

This systematic review of population based studies which have examined the relationship between lung function and lung cancer has produced several interesting observations. Firstly, independent of cigarette smoking history, reduced $\mathrm{FEV}_{1}$ increases the risk for lung cancer in the general population. Secondly, the relationship is severity dependent such that individuals with the worst lung function have the highest risk whereas those with preserved lung function have the lowest risk. Thirdly, the relationship is alinear; relatively small differences in $\mathrm{FEV}_{1}$ which are commonly considered within the normal range (for example, from $90 \%$ of predicted to $100 \%$ of predicted) increase the risk of lung cancer by 30 $60 \%$. Fourthly, the risk appears to be amplified in women.

The finding that reduced $\mathrm{FEV}_{1}$ at baseline is significantly associated with an increased risk of lung cancer is consistent with several previous reports. ${ }^{7815-21}$ Although baseline health status, degree of abnormality in lung function, and length of follow up varied considerably between the various cohorts, the associations were remarkably similar.

There are several possible explanations for a relationship between lung function and lung cancer. Firstly, the outcomes

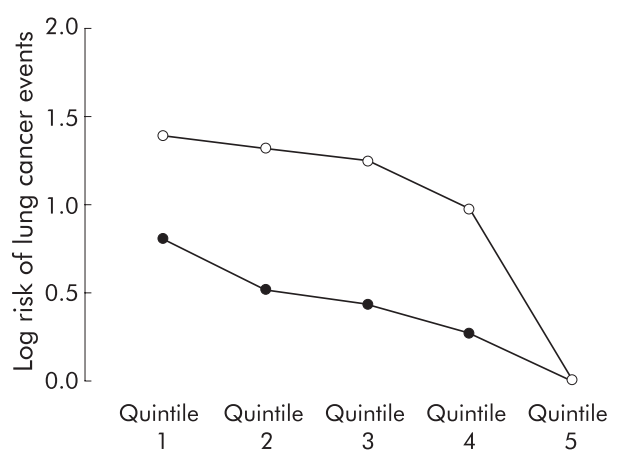

Figure 2 Risk of lung cancer in men and women on a natural logarithmic scale. Open circles are data for women and solid circles are data for men; $p<0.001$ for the comparison of slopes between men and women.

may share a causal pathway. One possible shared pathway is lung and airway inflammation which are known to correlate with the decline in lung function among smokers. ${ }^{22} 23$ Inflammation is thought to be an important mechanism responsible for the proteolytic lung destruction and small airway remodelling and narrowing which reduce lung function in smokers and in chronic obstructive pulmonary disease (COPD), ${ }^{22}$ and is also implicated in the decline in lung function in asthma ${ }^{24}$ and pulmonary fibrosis. ${ }^{25}$ Hence, reduced $\mathrm{FEV}_{1}$ may be part of the process related to lung and airway inflammation. Airway inflammation may also have a major role in the pathogenesis of lung cancer. ${ }^{26}$ Cigarette smoke and other noxious irritants incite a vigorous inflammatory reaction in the airways leading to the recruitment and activation of pro-inflammatory cells such as

Table 3 Relative risk (with 95\% confidence interval) of lung cancer for men and women in different quintiles of lung function

\begin{tabular}{|c|c|c|c|c|c|}
\hline & Quintile 1 & Quintile 2 & Quintile 3 & Quintile 4 & Quintile 5 \\
\hline \multicolumn{6}{|l|}{ Men } \\
\hline $\mathrm{Hole}^{10}$ & 2.53 (1.68 to 3.82 ) & 1.93 (1.27 to 2.94$)$ & 1.80 (1.17 to 2.77$)$ & $1.36(0.86$ to 2.16$)$ & 1.00 \\
\hline Kuller ${ }^{11}$ & $3.56(1.02$ to 12.43$)$ & $2.44(1.17$ to 5.05$)$ & 2.80 (1.32 to 5.93$)$ & $0.50(0.11$ to 2.34$)$ & 1.00 \\
\hline Mannino $^{12}$ & $3.16(1.20$ to 8.33$)$ & $1.03(0.35$ to 3.06$)$ & $1.11(0.35$ to 3.46$)$ & $0.94(0.29$ to 3.10$)$ & 1.00 \\
\hline Van Den Eeden ${ }^{13}$ & $1.86(1.32$ to 2.64$)$ & $1.60(1.35$ to 1.90$)$ & $1.45(1.20$ to 1.75$)$ & 1.34 (1.04 to 1.72$)$ & 1.00 \\
\hline Pooled summary & 2.23 (1.73 to 2.86$)$ & 1.67 (1.42 to 1.93$)$ & 1.54 (1.30 to 1.82$)$ & 1.30 (1.05 to 1.62$)$ & 1.00 \\
\hline \multicolumn{6}{|l|}{ Women } \\
\hline $\mathrm{Hole}^{10}$ & 4.39 ( 1.86 to 10.38$)$ & 4.14 (1.73 to 9.87$)$ & 4.01 (1.68 to 9.58 ) & $3.63(1.51$ to 8.76$)$ & 1.00 \\
\hline Mannino $^{12}$ & $5.99(0.75$ to 47.94$)$ & 8.58 (1.09 to 67.36$)$ & $8.76(1.09$ to 70.11$)$ & $1.08(0.07$ to 17.29$)$ & 1.00 \\
\hline Van Den Eeden ${ }^{13}$ & $1.95(0.32$ to 11.70$)$ & $1.45(0.27$ to 7.69$)$ & $1.80(0.52$ to 6.30$)$ & $1.55(0.41$ to 5.81$)$ & 1.00 \\
\hline Pooled summary & 3.97 (1.93 to 8.25$)$ & $3.71(1.80$ to 7.69$)$ & $3.46(1.75$ to 6.75$)$ & $2.64(1.30$ to 5.31$)$ & 1.00 \\
\hline $\begin{array}{l}\text { Pooled summary for men } \\
\text { and women }\end{array}$ & 2.36 (1.88 to 3.00$)$ & 1.72 (1.48 to 1.99 ) & 1.62 (1.38 to 1.90$)$ & $1.38(1.13$ to 1.70$)$ & 1.00 \\
\hline
\end{tabular}

All data were merged using a fixed effects model because there was no significant heterogeneity in data across the studies ( $p>0.10$ ). 
Table 4 Published studies on the association between impaired lung function $\left(\mathrm{FEV}_{1}\right)$ and the risk of lung cancer morbidity or mortality

\begin{tabular}{|c|c|c|c|c|c|c|c|c|c|}
\hline Study & Population & $\begin{array}{l}\text { Sample } \\
\text { size }\end{array}$ & $\begin{array}{l}\text { Women } \\
\text { (\%) }\end{array}$ & $\begin{array}{l}\text { Age } \\
\text { (years) }\end{array}$ & $\begin{array}{l}\text { Current } \\
\text { smokers (\%) }\end{array}$ & Outcome, $n$ & $\begin{array}{l}\text { Years of } \\
\text { follow up }\end{array}$ & Comparison & Adjusted factors \\
\hline Islam ${ }^{15}$ & $\begin{array}{l}\text { Tecumseh Community } \\
\text { population in Detroit }\end{array}$ & 3956 & 53.1 & $\geqslant 25$ & 43.9 & Incidence, 77 & 25 & $\begin{array}{l}\text { Predictor: } \mathrm{FEV}_{1} \% \text { pred } \\
\text { Every } 1 \text { unit decrease of } \\
\mathrm{FEV}_{1} \% \text { pred, regression } \\
\text { coefficient } 0.016 \\
\mathrm{p}=0.017\end{array}$ & $\begin{array}{l}\text { Age, sex, smoking } \\
\text { history }\end{array}$ \\
\hline Nomura $^{16}$ & $\begin{array}{l}\text { Japanese-American } \\
\text { men on Hawaiian } \\
\text { island of Oahu }\end{array}$ & 6317 & 0 & $\geqslant 45$ & 47.0 & Incidence, 172 & 22 & $\begin{array}{l}\text { Predictor: } \mathrm{FEV}_{1} \% \text { pred } \\
\text { quartile } \\
\text { Quartile } 3 \vee 4: \mathrm{RR}=1.0 \\
(0.6 \text { to } 1.9)^{*} \\
\text { Quartile } 2 \vee 4: \mathrm{RR}=2.5 \\
(1.5 \text { to } 4.1)^{*} \\
\text { Quartile } 1 \vee 4: \mathrm{RR}=2.1 \\
(1.3 \text { to } 3.5)^{*}\end{array}$ & $\begin{array}{l}\text { Age, detailed smoking } \\
\text { information }\end{array}$ \\
\hline Speizer ${ }^{17}$ & $\begin{array}{l}\text { Random sample of } \\
\text { community white adults } \\
\text { from six US cities }\end{array}$ & 8427 & 54.8 & $25-74$ & 39.8 & Mortality, 61 & $9-12$ & $\begin{array}{l}\text { Predictor: } F E V_{1} \text { quartile } \\
\text { Quartile } 3 \vee 4: R R=3.99 \\
\text { Quartile } 2 \vee 4: R R=2.00 \\
\text { Quartile } 1 \vee 4: R R=8.27\end{array}$ & \\
\hline Vestbo ${ }^{18}$ & $\begin{array}{l}\text { Random sample of all } \\
\text { men in Aalborg, } \\
\text { Denmark }\end{array}$ & 876 & 0 & $\geqslant 46$ & NR & Incidence $\%, 35$ & 11 & $\begin{array}{l}\text { Predictor: } \mathrm{FEV}_{1} \% / \mathrm{H}^{3} \dagger \\
\text { Per litre below expected } \\
\mathrm{FEV} \text { given height: } \\
\mathrm{RR}=2.1(1.3 \text { to } 3.4)^{*}\end{array}$ & Age, smoking status \\
\hline Lange $^{8}$ & $\begin{array}{l}\text { Random sample of } \\
\text { general population } \\
\text { in Copenhagen }\end{array}$ & 13946 & 54.3 & $\geqslant 20$ & 63.0 & Mortality, 225 & 10 & $\begin{array}{l}\text { Predictor: } \mathrm{FEV}_{1} \% \text { pred } \\
40-79 \% v \geqslant 80 \%: \\
\mathrm{RR}=2.1 \quad(1.3 \text { to } 3.4)^{*} \\
<40 v \geqslant 80: \\
\mathrm{RR}=3.9(2.2 \text { to } 7.2)^{*}\end{array}$ & $\begin{array}{l}\text { Age, sex, smoking } \\
\text { history, chronic } \\
\text { phlegm. }\end{array}$ \\
\hline Tockman $^{7}$ & $\begin{array}{l}\text { White American men } \\
\text { including a sample of } \\
\text { patients with moderate } \\
\text { to severe obstruction } \\
\text { from the IPPB Trial and } \\
\text { cigarette smoking } \\
\text { volunteers from JHLP }\end{array}$ & $\begin{array}{l}\text { IPPB: } 667 \\
\text { JHLP: } 3728\end{array}$ & 0 & $\geqslant 45$ & NR & $\begin{array}{l}\text { Mortality, } \\
\text { IPPB: } 22 \\
\text { JHLP: } 41\end{array}$ & $\begin{array}{l}\text { IPPB: } 3.0 \\
\text { JHLP: } 1.2\end{array}$ & $\begin{array}{l}\text { Predictor: } \mathrm{FEV}_{1} \% \text { pred } \\
\text { IPPB: } \\
<60 \% v \geqslant 60 \% \text { : } \\
\text { RR }=4.85, \mathrm{p}=0.002 \\
\mathrm{JHLP}: \\
60-85 \% v>85 \% \text { : } \\
\mathrm{RR}=2.57, \mathrm{p}=0.043 \\
<60 \% v>85 \% \text { : } \\
\mathrm{RR}=2.72, \mathrm{p}=0.062\end{array}$ & $\begin{array}{l}\text { Age, } \\
\text { pack-years, bronchitis, } \\
\text { shortness of breath }\end{array}$ \\
\hline Peto $^{19}$ & $\begin{array}{l}\text { Random sample of } \\
\text { men from the Vale of } \\
\text { Glamorgan and } \\
\text { employees in two } \\
\text { UK institutions }\end{array}$ & 2718 & 0 & $30-64$ & NR & Mortality, 103 & $20-25$ & $\begin{array}{l}\text { Predictor: } \mathrm{FEV}_{1} \% / \mathrm{H}^{3} \dagger \\
0-1 \text { SD below average } \\
v>\text { average: } \\
\mathrm{RR}=2.17 \ddagger \\
1-2 \text { SD below average } \\
v>\text { average: } \\
\mathrm{RR}=2.02 \ddagger \\
>2 \text { SD below average } \\
v>\text { average: } \\
\mathrm{RR}=1.89 \ddagger\end{array}$ & $\begin{array}{l}\text { Stratified by age } \\
\text { group and area }\end{array}$ \\
\hline Wiles $^{20}$ & $\begin{array}{l}\text { Random sample of } \\
\text { male gold miners in } \\
\text { South Africa }\end{array}$ & 2065 & 0 & $45-54$ & NR & Mortality, 74 & $16-18$ & $\begin{array}{l}\text { Predictor: } \mathrm{FEV}_{1} / \mathrm{H}^{3} \dagger \\
0-1 \text { SD below average } \\
v>\text { average: } \\
\mathrm{RR}=1.69 \ddagger \\
1-2 \text { SD below average } \\
v>\text { average: } \\
\mathrm{RR}=2.65 \ddagger \\
>2 \text { SD below average } \\
v>\text { average: } \\
\mathrm{RR}=2.87 \ddagger\end{array}$ & $\begin{array}{l}\text { Stratified by age } \\
\text { group }\end{array}$ \\
\hline
\end{tabular}

$\mathrm{SD}$, standard deviation; FEV 1 , forced expiratory volume in 1 second; RR, relative risk; NR, not reported; IPPB, Intermittent Positive Pressure Breathing Trial; JHLP, Johns Hopkins Lung Project. *Relative risk and $95 \%$ confidence interval.

tRatio of $\mathrm{FEV}_{1}$ to standing height ${ }^{3}$.

†RR was derived by comparison of the ratios (observed/expected) in different groups. Expected deaths were determined using log rank method.

- Respiratory cancer.

leucocytes which, in turn, propagate the inflammatory cascade through the release of various cytokines and reactive oxidative species. ${ }^{27}$ These latter molecules can cause oxidative damage and promote DNA mutagenesis in the surrounding lung cells. ${ }^{28}$ If the rate of cell division exceeds the rate at which reactive oxidative species related DNA damage can be repaired, DNA mutagenesis may occur and the risk for cancer increases. ${ }^{28}$ Reactive oxidative species may also directly activate various oncogenes in the surrounding cells and tissues (for example, jun and fos) which may further increase the risk of lung cancer. ${ }^{29}$ Consistent with this inflammatory hypothesis for lung cancer, the incidence of lung cancer is increased in inflammatory lung conditions such as idiopathic pulmonary fibrosis, ${ }^{30}$ asbestosis, and sarcoidosis. ${ }^{31}$ A corollary of the "shared pathogenesis" hypothesis is that the genes which impart risk for COPD and lung cancer may be common. For instance, individuals who have polymorphisms in genes which influence the oxidant/antioxidant balance in favour of reactive oxidative species may be susceptible to both.

A second possible explanation for the relationship is that the lung dysfunction secondarily enhances the risk of cancer. Individuals who have reduced $\mathrm{FEV}_{1}$ may have an impaired 
ability to clear inhaled carcinogens from their airways. This could lead to increased contact time between carcinogens and airway epithelial cells. However, this seems unlikely because individuals in quintiles 3 and 4 had "normal" FEV levels and yet had an increased risk of lung cancer.

In the present study the relationship between $\mathrm{FEV}_{1}$ and lung cancer was modified by sex. Whether women are more susceptible to lung cancer than men is controversial. Several epidemiological studies have reported data indicating increased susceptibility for lung cancer in women compared with men. ${ }^{32}{ }^{33}$ However, other studies have shown the reverse, with men being more susceptible to lung cancer than women, ${ }^{34}$ while other studies have demonstrated equal susceptibility. ${ }^{35}{ }^{36}$ Notwithstanding these data, there is little doubt that there are important biological and histological differences in lung cancer between women and men. For instance, in women, adenocarcinoma is by far the leading histological subtype of lung cancer whereas, in men, squamous and adenocarcinomas are equally prevalent. ${ }^{37}$ Interestingly, the contribution of cigarette smoking to the risk is less apparent for adenocarcinomas than for all other histological subtypes. ${ }^{38}$ Although lung cancer is rare in lifetime non-smokers, if it develops in these individuals it is usually an adenocarcinoma. ${ }^{39}$ Moreover, smoking cessation rapidly reduces the risk for squamous cell carcinoma while the risk for adenocarcinomas decreases much more slowly. ${ }^{40}$ In general, women have a higher frequency of GC $\rightarrow$ TA mutations $^{41}$ and transversions ${ }^{42}$ in the $\mathrm{p} 53$ gene in resected lung tumour specimens than men, even though the level of exposure to carcinogens from cigarette smoking may be lower in women ${ }^{41}$ Furthermore, higher levels of smoking related hydrophobic DNA adducts have been reported in the lung cancers and adjacent tissues in women. ${ }^{43}{ }^{44}$ Female smokers also exhibit significantly higher expression levels of lung CYPlAl than men. ${ }^{45}$ Increased CYPlAl expression is important in determining individual susceptibility to lung cancer and may be a critical factor for influencing differences between sexes in levels of aromatic/hydrophobic DNA adducts in the lung..$^{45}$ A lower DNA repair capacity in women than in men may also contribute to the variation in susceptibility between women and men. ${ }^{47}$

There are several limitations to this study. Cigarette smoking is a risk factor for lung function ${ }^{11}{ }^{12}$ and lung cancer $^{37}$ and could confound the relationships observed between $\mathrm{FEV}_{1}$ and lung cancer. However, all of the original studies included in the meta-analysis carefully controlled for the effects of cigarette smoking, making it unlikely that our results could be explained away by smoking. Nevertheless, we cannot fully discount the possibility of residual confounding by smoking. Secondly, we did not have data on the specific histological subtypes of cancer so the relationship between $\mathrm{FEV}_{1}$ and specific histological subtypes of lung cancer remains largely unknown, although the results of a previous study suggest that adenocarcinomas are more likely to develop in those who have small decreases in $\mathrm{FEV}_{1}$ and squamous cell carcinomas are more likely in those with severe impairment of lung function. ${ }^{48}$ Thirdly, publication bias is a concern. To mitigate this bias we chose only large population based studies. Since small positive studies are more likely to get published than small negative studies, by not including results from small studies the relative risk estimates of reduced $\mathrm{FEV}_{1}$ of the current meta-analysis may be lower than those previously published..$^{77}$ Fourthly, most of the original studies were conducted in relatively young individuals, so the findings of the present meta-analysis may not be generalisable to the older population who develop lung cancer.

Lung cancer is the most lethal cancer in the world. The only reasonable chance for cure is to uncover the disease at a localised stage. However, patients are rarely symptomatic at early stages of disease when curative resection would be possible. Most patients present at advanced stages of the disease, so screening and early diagnosis of lung cancer are therefore imperative in reducing case fatality rates. The present study demonstrates a strong inverse relationship between $\mathrm{FEV}_{1}$ and lung cancer which applies to all levels of $\mathrm{FEV}_{1}$. The risk increases even with a relatively modest reduction in $\mathrm{FEV}_{1}$, especially among women. We found that women were approximately twice as likely to develop lung cancer as men for the same marginal decrements in $\mathrm{FEV}_{1}$. The potential clinical implication is that, in smokers and former smokers, $\mathrm{FEV}_{1}$ may provide criteria beyond age and smoking intensity to identify smokers at high risk for lung cancer; this discriminatory power of lung function testing may be important in selecting smokers for enrollment in chemoprevention and early detection trials. Furthermore, since lung cancer can occur in individuals with only small decreases in $\mathrm{FEV}_{1}$ (especially in women), the traditional boundaries of "normal" $\mathrm{FEV}_{1}$ may need to be modified for screening purposes.

\section{Authors' affiliations}

S Wasswa-Kintu, W Q Gan, S F P Man, P D Pare, D D Sin, Department of Medicine (Respiratory Division), University of British Columbia and The James Hogg iCAPTURE Center for Cardiovascular and Pulmonary Research, St Paul's Hospital, Vancouver, British Columbia, Canada

DDS is supported by a Canada Research Chair (Respiration) and a Michael Smith/St Paul's Hospital Foundation Professorship in COPD.

\section{REFERENCES}

1 Ezzati M, Lopez AD. Estimates of global mortality attributable to smoking in 2000. Lancet 2003;13, 362:847-52.

2 Bray F, Sankila R, Ferlay J, et al. Estimates of cancer incidence and mortality in Europe in 1995. Eur J Cancer 2002;38:99-166.

3 Jemal A, Tiwari RC, Murray T, et al. Cancer statistics 2004. CA Cancer J Clin 2004;54:8-29.

4 Boffetta P. Epidemiology of environmental and occupational cancer. Oncogene 2004;23:6392-403.

5 Gottschall EB. Occupational and environmental thoracic malignancies. J Thorac Imaging 2002;17:189-97.

6 Skillrud DM, Offord KP, Miller RD. Higher risk of lung cancer in chronic obstructive pulmonary disease: a prospective, matched, controlled study. Ann Intern Med 1986; 105:503-7.

7 Tockman MS, Anthonisen NR, Wright EC, et al. Airways obstruction and the risk for lung cancer. Ann Intern Med 1987;106:512-8.

8 Lange $\mathbf{P}$, Nyboe J, Appleyard $M$, et al. Ventilatory function and chronic mucus hypersecretion as predictors of death from lung cancer. Am Rev Respir Dis 1990;141:613-7.

9 Sutton AJ, Abrams KR. Methods for meta-analysis in medical research. Chichester, UK: John Wiley, 2000:57-6.

10 Hole DJ, Watt GCM, Davey Smith G, et al. Impaired lung function and mortality risk in men and women: findings from the Renfrew and Paisley prospective study population. BMJ 1996;313:711-5.

11 Kuller LH, Ockene J, Meilahn E, et al. Relation of forced expiratory volume in one second $\left(\mathrm{FEV}_{1}\right)$ to lung cancer mortality in the multiple risk factor intervention trial (MRFIT). Am J Epidemiol 1990;132:265-74.

12 Mannino DM, Aguayo SM, Petty TL, et al. Low lung function and incident lung cancer in the United States: data from the First National Health and Nutrition Examination Survey follow-up. Arch Intern Med 2003;163:1475-80.

13 Van Den Eeden SK, Friedman GD. Forced expiratory volume (1 second) and lung cancer incidence and mortality. Epidemiology 1992;3:253-7.

14 National Center for Health Statistics. National Health and Nutrition Examination Survey. Available at http://www.cdc.gov/nchs/nhanes.htm (accessed 9 February 2005).

15 Islam SS, Schottenfeld D. Declining $\mathrm{FEV}_{1}$ and chronic productive cough in cigarette smokers: a 25-year prospective study of lung cancer incidence in Tecumseh, Michigan. Cancer Epidemiol Biomarkers Prev 1994;3:289-98.

16 Nomura A, Stemmermann GN, Chyou PH, et al. Prospective study of pulmonary function and lung cancer. Am Rev Respir Dis 1991;144:307-1 1.

17 Speizer FE, Fay ME, Dockery DW, et al. Chronic obstructive pulmonary disease mortality in six US cities. Am Rev Respir Dis 1989;140:49-55.

18 Vestbo J, Knudsen KM, Rasmussen FV. Are respiratory symptoms and chronic airflow limitation really associated with an increased risk of respiratory cancer? Int J Epidemiol 1991;20:375-8.

19 Peto R, Speizer FE, Cochrane AL, et al. The relevance in adults of air-flow obstruction, but not of mucus hypersecretion, to mortality from chronic lung disease. Results from 20 years of prospective observation. Am Rev Respir Dis 1983; 128:491-500. 
20 Wiles FJ, Hnizdo E. Relevance of airflow obstruction and mucus hypersecretion to mortality. Respir Med 1991;85:27-35.

21 Eberly LE, Ockene J, Sherwin R, et al. Pulmonary function as a predictor of lung cancer mortality in continuing cigarette smokers and in quitters. Int J Epidemiol 2003:32:592-9.

22 Hogg JC, Chu F, Utokaparch S, et al. The nature of small-airway obstruction in chronic obstructive pulmonary disease. N Engl J Med 2004;350:2645-53.

23 Cosio M, Ghezzo H, Hogg JC, et al. The relations between structural changes in small airways and pulmonary-function tests. N Engl J Med 1978:298:1277-81

24 Vignola AM, Mirabella F, Costanzo G, et al. Airway remodeling in asthma. Chest 2003; 123:417-22.

25 Gross TJ, Hunninghake GW. Idiopathic pulmonary fibrosis. N Engl J Med 2001;345:517-25.

26 Ballaz S, Mulshine JL. The potential contributions of chronic inflammation to lung carcinogenesis. Clin Lung Cancer 2003;5:46-62.

27 Barnes PJ, Shapiro SD, Pauwels RA. Chronic obstructive pulmonary disease: molecular and cellular mechanisms. Eur Respir J 2003;22:672-88.

28 Ames BN, Shigenaga MK, Gold LS. DNA lesions, inducible DNA repair, and cell division: three key factors in mutagenesis and carcinogenesis. Environ Health Perspect 1993; 101:35-44.

29 Wodrich W, Volm M. Overexpression of oncoproteins in non-small cell lung carcinomas of smokers. Carcinogenesis 1993;14:1121-4.

30 Lee HJ, Im JG, Ahn JM, et al. Lung cancer in patients with idiopathic pulmonary fibrosis: CT findings. J Comput Assist Tomogr 1996;20:979-82.

31 Bouros D, Hatzakis K, Labrakis $\mathrm{H}$, ef al. Association of malignancy with diseases causing interstitial pulmonary changes. Chest 2002;121:1278-89.

32 Risch HA, Howe GR, Jain M, et al. Are female smokers at higher risk for lung cancer than male smokers? A case-control analysis by histologic type. Am J Epidemiol 1993;138:281-93.

33 Zang EA, Wynder EL. Differences in lung cancer risk between men and women: examination of the evidence. J Natl Cancer Inst 1996;88:183-92.

34 Halpern MT, Gillespie BW, Warner KE. Patterns of absolute risk of lung cancer mortality in former smokers. J Natl Cancer Inst 1993;85:457-64.

35 Bach PB, Kattan MW, Thornquist MD, et al. Variations in lung cancer risk among smokers. J Natl Cancer Inst 2003;95:470-8.

36 Bain C, Feskanich D, Speizer FE, et al. Lung cancer rates in men and women with comparable histories of smoking. J Natl Cancer Inst 2004;96:826-34.
37 Patel JD, Bach PB, Kris MG. Lung cancer in US women: a contemporary epidemic. JAMA 2004;291:1763-8.

38 Khuder SA. Effect of cigarette smoking on major histological types of lung cancer: a meta-analysis. Lung Cancer 2001;31:139-48.

39 Nordquist LT, Simon GR, Cantor A, et al. Improved survival in never-smokers vs current smokers with primary adenocarcinoma of the lung. Chest 2004; 126:347-51.

40 Jedrychowski W, Becher $\mathrm{H}$, Wahrendorf J, et al. Effect of tobacco smoking on various histological types of lung cancer. J Cancer Res Clin Oncol 1992; 118:276-82.

41 Kure EH, Ryberg D, Hewer A, et al. p53 Mutations in lung tumours: relationship to gender and lung DNA adduct levels. Carcinogenesis 1996;17:2201-5.

42 Toyooka S, Tsuda T, Gazdar AF. The TP53 gene, tobacco exposure, and lung cancer. Hum Mutat 2003;21:229-39.

43 Ryberg D, Hewer A, Phillips DH, et al. Different susceptibility to smokinginduced DNA damage among male and female lung cancer patients. Cancer Res 1994;54:5801-3.

44 Mollerup S, Ryberg D, Hewer A, et al. Sex differences in lung CYPIA1 expression and DNA adduct levels among lung cancer patients. Cancer Res 1999:59:3317-33.

45 McLemore TL, Adelberg S, Liu MC, et al. Expression of CYP1Al gene in patients with lung cancer: evidence for cigarette smoke-induced gene expression in normal lung tissue and for altered gene regulation in primary pulmonary carcinomas. J Natl Cancer Inst 1990;82:1333-9.

46 Guengerich FP, Shimada T. Oxidation of toxic and carcinogenic chemicals by human cytochrome P-450 enzymes. Chem Res Toxicol 1991;4:391-407.

47 Wei Q, Cheng L, Amos Cl, et al. Repair of tobacco carcinogen-induced DNA adducts and lung cancer risk: a molecular epidemiologic study. J Natl Cancer Inst 2000;92:1764-72.

48 Papi A, Casoni G, Caramori G, et al. COPD increases the risk of squamous histological subtype in smokers who develop non-small cell lung carcinoma. Thorax 2004;59:679-81.

49 Hankinson JL, Odencrantz JR, Fedan KB. Spirometric reference values from a sample of the general US population. Am J Respir Crit Care Med 1999; 159:179-87. 


\section{PostScript}

\section{LETTERS TO THE EDITOR}

If you have a burning desire to respond to a paper published in Thorax, why not make use of our "rapid response" option?

Log on to our website (www.thoraxinl. com), find the paper that interests you, and send your response via email by clicking on the "eletters" option in the box at the top right hand corner.

Providing it isn't libellous or obscene, it will be posted within seven days. You can retrieve it by clicking on "read eletters" on our homepage.

The editors will decide as before whether to also publish it in a future paper issue.

\section{TIMP-3 promoter gene polymorphisms in BFL}

Bird fanciers' lung (BFL) is a form of hypersensitivity pneumonitis induced by inhalation of antigens from birds. ${ }^{1}$ Only a small percentage of bird fanciers will develop BFL, so it is likely that these patients have a certain genetic predisposition to the disease. ${ }^{1}$

Matrix metalloproteinases (MMP) are zinc enzymes responsible for the degradation of the extracellular matrix. The proteolytic activities of MMP are counter-regulated by tissue inhibitors of MMP (TIMP). Hill found a decreased carriership of the rare TIMP-3 $-1296 \mathrm{C}$ and $-915 \mathrm{G}$ promoter alleles in Mexican patients with pigeon induced BFL, suggesting a protective effect of these alleles against the development of this disease. ${ }^{2}$

Only two previously published genetic association studies to date have focused on the susceptibility to BFL and both were performed in Mexican pigeon breeders. ${ }^{23}$ We have undertaken a study to validate the association between BFL susceptibility in Mexicans and TIMP-3 promoter polymorphisms in a group of Dutch white patients with BFL.

Forty one patients with BFL (35 keeping pigeons, 10 keeping budgerigars, 3 keeping parrots and 1 keeping canaries; 19 women and 22 men) and 335 controls were genotyped using sequence specific primers and polymerase chain reaction. The diagnosis of BFL was established in concordance with the criteria used in the Mexican study. ${ }^{2}$ The control group comprised healthy employees from our hospital. We did not include a group of bird fanciers without BFL since Hill did not find differences in TIMP-3 allele distributions between Mexican controls with or without exposure to birds.

The Dutch population was in HardyWeinberg equilibrium. In contrast to the previous TIMP-3 study in Mexicans, we found $100 \%$ linkage between the $-1296 \mathrm{~T}$ and $-915 \mathrm{~A}$ alleles and between the $-1296 \mathrm{C}$ and $-915 \mathrm{G}$ alleles in subjects homozygous for the respective alleles. We were therefore able to deduce two haplotypes ( ${ }^{*} \mathrm{~T}^{*} \mathrm{~A}$ and ${ }^{*} \mathrm{C}^{*} \mathrm{G}$ ). The TIMP-3 ${ }^{*} \mathrm{C}^{*} \mathrm{G}$ haplotype frequency in BFL patients was significantly lower than in controls $(\mathrm{p}=0.0434 ;$ OR $0.513 \quad(95 \%$ CI 0.277 to $0.950 ; \mathrm{p}=0.0312$ ); table 1 ).

Hill described a similar association in Mexican patients with BFL. We found a reduction of the rarer TIMP-3 alleles in Dutch patients with BFL $(-1296 \mathrm{C}$ and $-915 \mathrm{G},-11 \%)$, comparable to the reduction found in Mexican BFL patients $(-1296 \mathrm{C}$, $-12.6 \%$; $-915 \mathrm{G},-10.8 \%$; table 1 ). However, there were differences between the findings of the two studies. The TIMP-3 $-1296 \mathrm{C}$ and $-915 \mathrm{G}$ allele frequencies in Dutch controls were significantly lower than in the Mexican controls $(-1296 \mathrm{C}, \quad \mathrm{p}=0.0008 ;-915 \mathrm{G}$, $\mathrm{p}=0.0183$; table 1$).^{2}$ A search on the National Center for Biotechnology Information website showed similar TIMP-3 $-1296 \mathrm{C}$ frequencies in Dutch and American controls (30 mother-father-child trios from Utah with northern and/or western European ancestry; http://www.ncbi.nih.gov/SNP/snp viewTable.cgi?pop = 1409; http://www.ncbi. nih.gov/SNP/snp_ref.cgi?rs $=9619311)$. BFL in Mexicans has a similarly poor prognosis to idiopathic pulmonary fibrosis, which contrasts with the more benign clinical course in Europeans. ${ }^{45}$ Although most patients in our study had severe symptoms at presentation with profound pulmonary function abnormalities, symptoms and pulmonary function improved in the majority of cases during follow up. Furthermore, we included an approximately equal number of male and female patients and bird fanciers who kept birds other than pigeons, while all the Mexican patients were female and kept pigeons only. ${ }^{2}$ Despite these genotypical and phenotypical differences, the rarer TIMP-3 promoter alleles were protective in both ethnic populations which makes an underlying functional cause of the ${ }^{*} \mathrm{C}^{*} \mathrm{G}$ haplotype likely. ${ }^{2}$

In conclusion, we found a decreased carriership of the TIMP- $3{ }^{*} C^{*} G$ haplotype in Dutch patients with BFL, indicating a protective effect against the development of this disease. Studying the influence of polymorphisms on disease susceptibility in multiple ethnically and

Table 1 TIMP3 - 1296T $>C$ and $-915 A>G$ allele frequencies in Mexican and Dutch controls and BFL patients

\begin{tabular}{|c|c|c|c|c|c|}
\hline & \multicolumn{2}{|c|}{ TIMP3 $-1296 \mathrm{~T}>\mathrm{C}$} & & \multicolumn{2}{|c|}{ TIMP3 $-915 A>G$} \\
\hline & Mexican $^{2}$ & Dutch & & Mexican $^{2}$ & Dutch \\
\hline Controls & $(n=323)$ & $(n=335)$ & Controls & $(n=323)$ & $(n=335)$ \\
\hline $\mathrm{T}$ & $416(64.4)$ & $490(73.1)$ & A & $433(67.0)$ & $490(73.1)$ \\
\hline C & $230(35.6)$ & $180(26.9)$ & G & 213 (33.0) & $180(26.9)$ \\
\hline BFL & $(n=115)$ & $(n=41)$ & BFL & $(n=115)$ & $(n=41)$ \\
\hline$T$ & $177(77.0)$ & $69(84.1)$ & $A$ & $179(77.8)$ & $69(84.1)$ \\
\hline C & $53(23.0)$ & $13(15.9)$ & G & $51(22.2)$ & $13(15.9)$ \\
\hline
\end{tabular}

Data are given as absolute numbers with percentages in parentheses. geographically distinct disease and control populations is important. Our study is the first to confirm an association between polymorphisms and susceptibility to BFL, which adds importance to the relationship between TIMP-3 promoter polymorphisms and BFL. However, the mechanism by which the TIMP-3 variants may cause such a protective effect has yet to be determined.

The authors thank Hatice Alpar, Jan Broess and Helga Dissel for their technical support.

R Janssen, A Kruit, J C Grutters Heart Lung Center Utrecht, Department of Pulmonology, St Antonius Hospital, Nieuwegein, The Netherlands

H J T Ruven

Department of Clinical Chemistry, St Antonius Hospital, Nieuwegein, The Netherlands

C M H van Moorsel, J M M van den Bosch Heart Lung Center Utrecht, Department of Pulmonology, St Antonius Hospital, Nieuwegein, The Netherlands

Correspondence to: Dr J C Grutters, Department of Pulmonology, St Antonius Hospital, Koekoekslaan 1 3435 CM Nieuwegein, The Netherlands; i.grutters@ antonius.net

doi: $10.1136 /$ thx.2005.046581

\section{References}

1 Bourke SJ, Dalphin JC, Boyd G, et al. Hypersensitivity pneumonitis: current concepts. Eur Respir J 2001;32:81-92s.

2 Hill MR, Briggs L, Montano MM, et al. Promoter variants in tissue inhibitor of metalloproteinase-3 (TIMP-3) protect against susceptibility in pigeon breeders' disease. Thorax 2004;59:586-90.

3 Camarena A, Juarez A, Mejia M, et al. Major histocompatibility complex and tumor necrosis factor-alpha polymorphisms in pigeon breeder's disease. Am J Respir Crit Care Med 2001; 163:1528-33.

4 Sansores R, Salas J, Chapela R, et al. Clubbing in hypersensitivity pneumonitis. Arch Intern Med 1990; 150:1849-51

5 Bourke SJ, Banham SW, Carter R, et al. Longitudinal course of extrinsic allergic alveolitis in pigeon breeders. Thorax 1989;44:415-8.

\section{Late CF caused by homozygous IVS8-5T CFTR polymorphism}

The distribution of cystic fibrosis (CF) transmembrane conductance regulator (CFTR) genotypes is not well characterised in patients with CF diagnosed after childhood, the majority of whom are compound heterozygotes for $\Delta \mathrm{F} 508{ }^{1}$ We describe such a patient with a rare genotype more commonly associated with inherited infertility in males.

A 54 year old man who had never smoked was referred with bilateral bronchiectasis and chronic sinusitis. He had no known allergy, no history of pancreatitis, and no family history of CF or consanguinity. Obstructive infertility with azoospermia had been established by spermography. The patient reported recurrent lower respiratory tract infections since childhood and pneumonia at the age of 45 . He had undergone sinus surgery for nasal polyposis.

CF was suspected. A first sweat test was positive with a chloride concentration of $65 \mathrm{mmol} / \mathrm{l}$ (normal $<40 \mathrm{mmol} / \mathrm{l}$ ). The patient had chronic cough productive of purulent sputum, mild dyspnoea, chronic nasal 
obstruction with nasal polyps and anosmia. His weight was $70 \mathrm{~kg}$ and his height $1.75 \mathrm{~m}$. He had no digestive symptoms. Lung and heart auscultation was normal. A chest CT scan showed diffuse bronchiectasis predominating in the right upper and left lower lobes (fig 1). Lung function was near normal with forced expiratory volume in 1 second $\left(\mathrm{FEV}_{1}\right)$ of $3.1 \mathrm{l}$ ( $89 \%$ predicted), $\mathrm{FEV}_{1} /$ forced vital capacity 0.73 , total lung capacity 7 litres $(100 \%$ predicted), and forced expiratory flow $25-75 \% 61 \%$ of predicted. Arterial oxygen tension was normal. Both sputum and bronchoalveolar lavage cultures were positive for mucinous Pseudomonas aeruginosa but no mycobacteria or fungi were found. Serological examination for Aspergillus fumigatus was negative. Exocrine pancreatic sufficiency was confirmed by normal elastase levels in the stools. A second sweat test was normal $(25 \mathrm{mmol} / \mathrm{l})$.

A screening test for the 22 most frequent mutations of the CFTR gene encountered in France was negative. However, mutations of the CFTR gene were confirmed by the presence of homozygozity for the $5 \mathrm{~T}$ allele in the polythymidine tract of intron 8 (IVS85T) with 11 TG repeats. The M470V polymorphism was absent. Sequencing of the full CFTR coding sequence including all 27 exons and the flanking splice sites showed no other mutation.

This patient had clinical features typical of CF involving several organs (bilateral bronchiectasis, chronic sinus disease, male infertility) together with two pathogenic CFTR gene mutations, so a diagnosis of nonclassic CF can be made. ${ }^{2}$ The sweat test was positive on only one of two occasions, suggesting partial dysfunction of the CFTR protein. ${ }^{1}$

The IVS8-5T allele is associated with poorly effective usage of the intron 8 splice acceptor site compared with the two other existing alleles (7T and 9T) and results in frequent skipping of exon 9. Patients homozygous for the IVS8-5T allele have lower than normal levels of full length CFTR messenger RNA ${ }^{3}$ and protein. Heterozygous IVS8-5T polymorphism is considered equivalent to a "mild" CFTR mutation. When in trans with a known CFTR mutation, the IVS8-5T allele may be responsible for congenital bilateral absence of the vas deferens or recurrent pancreatitis. ${ }^{4}$ It may modulate the variable expression of "mild" CFTR mutations such as when present in cis of the R117H mutation, thus causing a CF phenotype.

Compound heterozygotes with IVS8-5T and $\Delta$ F508 may present with classic or late onset CF. ${ }^{1}$ Whether IVS8-5T homozygosity may be sufficient by itself to cause disease has not hitherto been established. Nonclassic CF was reported in a 48 year old woman homozygous for IVS8-5T, but the M470V polymorphism and TG12 repeat sequence known to modulate the disease penetrance of IVS8-5T were also present. ${ }^{5}$

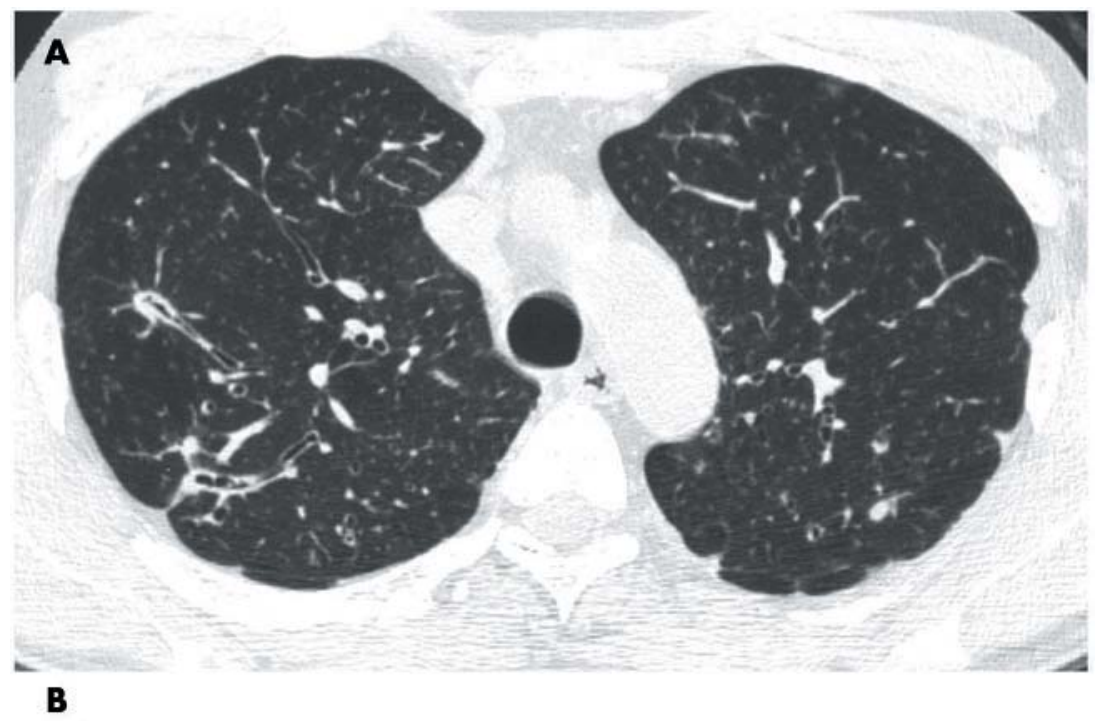

exon 9

reference $t a t t t t t g a t g t g t g t g t g t g t g t g t g t g t g t g t t t t t t t a a$ sequence TATTTTTGATGTGTGTGTGTGTGTGTGTGTGTTTTTA ACAGG

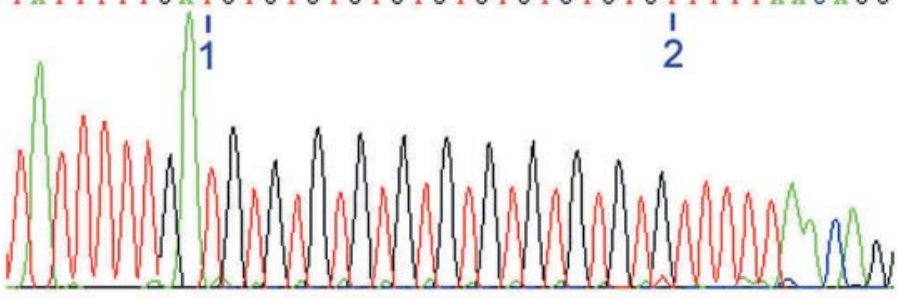

Figure 1 (A) Chest CT scan showing bronchiectasis and bronchial wall thickening predominating in the right upper lobes. (B) Sequencing of the IVS8 locus. 1 indicates the first T of the 11 TG repeats and 2 shows the first T of the 5T motif of the IVS8 locus. The reference DNA sequence is indicated as "reference" and the DNA sequence of the patient is indicated as "sequence".
This observation shows that individuals homozygous for the IVS8-5T allele as the sole variation of the whole CFTR coding sequence may present as non-classic CF with sinopulmonary disease and male infertility. However, given the high prevalence of the IVS8-5T allele (5-10\% in the general population), the expected frequency of individuals homozygous for IVS8-5T may be higher than the prevalence of $\mathrm{CF}$, suggesting that other factors may contribute to the disease. The IVS8-5T allele should be included in the systematic screening for CFTR mutations in patients with suspected or confirmed CF.

V Cottin*, Y Thibout*

Service de Pneumologie - Centre de Référence des Maladies Orphelines Pulmonaires, Hôpital Cardiovasculaire et Pneumologique Louis Pradel, Université Claude Bernard, Lyon, France

F Bey-Omar

Laboratoire de Biochimie et Biologie Endocrinienne et Moléculaire, Hôpital Debrousse, Lyon, France

I Durieu

Centre de Ressource et de Compétence sur la Mucoviscidose, Service de Médecine Interne, Centre Hospitalier Lyon-Sud, Pierre-Bénite, France

L Laoust

160 Place Charles de Gaulle, 74300 Cluses, France

Y Morel

Laboratoire de Biochimie et Biologie Endocrinienne et Moléculaire, Hôpital Debrousse, Lyon, France

J-F Cordier

Service de Pneumologie - Centre de Référence des Maladies Orphelines Pulmonaires, Hôpital Cardiovasculaire et Pneumologique Louis Pradel, Université Claude Bernard, Lyon, France

Correspondence to: $\mathrm{Dr} V$ Cottin, Hôpital Louis Pradel, 28 Avenue Doyen Lépine, 69677 Lyon, France; vincent.cottin@chu-lyon.fr

*Both authors contributed equally to this work. doi: $10.1136 /$ thx.2005.048207

\section{References}

1 Rodman DM, Polis JM, Heltshe SL, et al. Late diagnosis defines a unique population of longterm survivors of cystic fibrosis. Am J Respir Crit Care Med 2005;171:621-6.

2 Rosenstein BJ, Cutting GR. The diagnosis of cystic fibrosis: a consensus statement. Cystic Fibrosis Foundation Consensus Panel. J Pediatr 1998; 132:589-95

3 Chu CS, Trapnell BC, Curristin S, et al. Genetic basis of variable exon 9 skipping in cystic fibrosis transmembrane conductance regulator mRNA. Nat Genet 1993;3:151-6.

4 Boyle MP. Nonclassic cystic fibrosis and CFTRrelated diseases. Curr Opin Pulm Med 2003;9:498-503.

5 Noone PG, Pue CA, Zhou Z, et al. Lung disease associated with the IVS8 5T allele of the CFTR gene. Am J Respir Crit Care Med 2000;162:1919-24.

\section{CORRECTION}

doi: 10.1136/thx.2004.037135corrl

In the paper entitled "Relationship between reduced forced expiratory volume in one second and the risk of lung cancer: a systematic review and meta-analysis" by S Wasswa-Kintu et al which appeared on pages 570-575 of the July 2005 issue of Thorax, the correct figure for the worldwide mortality from lung cancer in 2000 (mentioned in the second line of the first paragraph) is 0.85 million, not 328 million as stated in the article. 